\title{
SEASONAL CHANGES IN OCCURRENCE OF Fusarium ISOLATES IN GRAIN WAREHOUSES
}

\section{SEZONOWE ZMIANY WYSTĘPOWANIA IZOLATÓW Fusarium W MAGAZYNACH ZBOŻOWYCH}

\author{
Independent Department of Biotechnology and Molecular Biology, University of Opole, Poland
}

\begin{abstract}
Streszczenie. Nasiona zbóż w skali globalnej dostarczają więcej energii, niż którekolwiek $z$ uprawianych roślin, gdyż są bogate $w$ węglowodany. W gospodarce światowej dominują uprawy takich gatunków zbóż, jak pszenica, jęczmień, kukurydza oraz ryż. Natomiast w Polsce ze względów klimatycznych uprawia się głównie: pszenicę, żyto, pszenżyto, jęczmienie, owies oraz kukurydzę. W łańcuchu produkcji rolno-spożywczej można wydzielić następujące etapy: uprawę, magazynowanie oraz przetwórstwo. Na każdym z tych etapów występują różne zagrożenia, w tym mykologiczne. Duży problem stanowią grzyby $\mathrm{z}$ rodzaju Fusarium i produkowane przez nie fuzariotoksyny. Grzyby te porażają zboża w uprawach, a także mogą utrudniać magazynowanie ziarna i prowadzić do pogorszenia jego jakości. Celem przeprowadzonych badań była ocena stopnia kontaminacji ziarna i przestrzeni przechowywania grzybami rodzaju Fusarium w trakcie magazynowania zbóż. Badania prowadzono w czterech okresach badawczych, w dwóch magazynach płaskich. Przeprowadzono analizę składu mykologicznego bioaerozolu magazynowego, powierzchni magazynowych, frakcji opadającej na powierzchnię magazynową oraz składowanego ziarna. Grzyby z rodzaju Fusarium stanowiły nieznaczną część izolatów w przestrzeni magazynowej. Stopień zanieczyszczenia przechowywanego ziarna grzybami Fusarium był zróżnicowany w badanych magazynach i zależał od jakości magazynowanego materiału, a także od czasu jego przechowywania. Stopień kontaminacji ziarna grzybami Fusarium sp. obniżał się w miarę wydłużania czasu przechowywania.
\end{abstract}

Key words: Fusarium, grain warehouses, temperature, relative humidity, air.

Słowa kluczowe: Fusarium, magazyny zbożowe, temperatura, wilgotność względna, powietrze.

\section{INTRODUCTION}

Cereals and semi-finished product of their processing are one of the main raw material sources in the food industry (Jiménez-Islas et al. 2004; Krnjaja et al. 2012). The most important stage in the food production chain is the storage of raw cereal and the products thereof. The purposes of the grain warehousing are: preservation of the proper conditions and the control of the quality losses (Kręcidło and Krzyśko-Łupicka 2016). The spoilage of grains caused by moulds during the storage process is a result of: inappropriate physicochemical conditions, presence of pests or holding of poor quality grains. The

Corresponding author - Adres do korospondencji: Łukasz Kręcidło, Independent Department of Biotechnology and Molecular Biology, University of Opole, Kardynała Bolesława Kominka 6, 46-020 Opole, Poland, e-mail: I.krecidlo@gmail.com 
occurrence of common storage moulds as Aspergillus or Penicillium is a major risk factor that may cause contamination of the grain. Also the phytopathogenic fungi, which are transferred onto surface of the grains from farmlands, may disperse and induce grains damage (Amiri and Bompeix 2005; Mohana and Raveesha 2007; Satish et al. 2008).

Fusarium species may be pathogens of human, animals or plants. They are among the main phytopathogenic moulds causing crop infections during harvesting. The growth of moulds belonging to genus Fusarium causes such commonly found crop field diseases as: Fusarium root rot, Fusarium crown rot (FCR) and Fusarium stalk (stem) rot, Fusarium ear blight or Fusarium head blight (Foroud et al. 2014). The most important Fusarium pathogens for polish crops belong to three groups. The first is the complex of $F$. graminearum isolates that are identified as causative agents of Fusarium head blight of wheat and barley and may contaminate the grain with trichothecene (Vanheule et al. 2014). The second group are the $F$. oxysporum isolates that cause the vascular wilt. Further lots of foot and root rot pathogens are a part of $F$. solani species complex which are able to infect various hosts (Aoki et al. 2014). The occurrence of Fusarium species during the harvesting and afterwards during the grain warehousing may lead to: decrease of field productivity, loss of a grain quality, changes in grain properties (colour, shape, weight) and reduction of germination of seeds (Demeke et al. 2005). Mycotoxins that are produced by Fusarium species are also the severe concern for the food production chain. Trichothecenes and deoxynivalenol (DON), are the most common substances released by Fusarium species. Their content in a cereal grain is various, fluctuates seasonally and depends on the year of cultivation. Recently, most studies are focused on the construction of models to predict the risk of trichothecenes contamination. Deoxynivalenol is the most common mycotoxin produced by moulds which contaminate crop products worldwide (Landschoot et al. 2012). DON may be accumulated in grains, and goods produced of them may cause adverse health effects in humans and animals (Champeil et al. 2004; Wegulo et al. 2015). Prevention activities are crucial to the food production chain so the monitoring of the growth of Fusarium species during harvesting and afterword may supply lots of important information for the risk assessment.

The purpose of the study was to assess the degree of contamination of grains and warehousing area by Fusarium species.

\section{MATERIAL AND METHODS}

The study was conducted in the years 2015-2016 in two flat warehouses with volumes of $12900 \mathrm{~m}^{3}$ and $12300 \mathrm{~m}^{3}$ for Warehouse I and Warehouse II respectively. Sample collection and data analysis were conducted for four study periods: I - before the filling of the flat warehouses (after disinfection); II - after filling the flat warehouses; III - during the warehousing period; IV - after the warehousing period. Wheat grain was stored in both warehouses. The storage area was filled with in $60 \%$ with grain. The physical conditions, as temperature and relative humidity $(\mathrm{RH})$, of the storage during the tests were determined using the APAR AR236 / 1 recorder.

In both flat warehouses, the assessment of the participation of Fusarium species in the total number of moulds present was conducted for: the air of the storage area, onto warehouses walls, the grains surface and for the fraction settling on storage surfaces. 
The total number of fungi on the storage surface was determined by execution of the swab test method with a series of dilutions. The research material was collected from the warehouses walls. In each of warehouses seven sampling sites were determined. The total number of moulds in the storage air were determined by the volumetric method using the one-stage impactor MAS-100 (Merck, Poland). The scheme of sampling devices placement was $1 \mathrm{~m}$ from the ground, $1 \mathrm{~m}$ from walls. The volume of air that impacted the head of the device was $50 \mathrm{dm}^{3}$ for each sample. The volume of the aspired air was chosen by a trial series for a high contaminated area. The number of moulds in the settling fraction of microorganisms was based on calculation of the Index of Microbial Contamination (IMC) suggested by Pasquarella and co-authors (2000 and 2014). The used exposition time for opened Petri dishes with proper medium was 10 minutes. The sampling site were the same as in other analysis. Stored grains were collected from a pile using a grain sampler. Seven samples of grain were collected from each warehouse.

Evaluation of the total number of moulds was done by the culture based method. The full synthetic medium Czapek-DOX (BTL, Poland) was used for the analyses. Petri dishes were incubated at $25^{\circ} \mathrm{C}$ for 7 days.

Identification of isolated moulds was done based on the morphological features using diagnostic keys (Pitt and Hocking 1985, 2013). The species names of the anamorphic form of that fungi were compared with the NCBI taxonomic database. The obtained results were statistically calculated for data transformed to logarithmic form. Statistical significance $(0.05 \geq p \geq 0.005)$ was determined using a one-way analysis of variance using the R program (The R Foundation, Austria). The results are presented as percentage of Fusarium fungi in the total number of moulds.

\section{RESULTS}

Microclimatic conditions were variable between sampling periods, but the temperature and the relative humidity were comparable in both warehouses during one sampling period. The highest air humidity was noted after filling both warehouses with wheat grain and the lowest humidity was measured during the unload period. The relative humidity of air did not exceed $70 \%$. The highest temperature, contrarily to the humidity, was obtained during the process of filling, but the lowest temperature was noted in the storage process. The fluctuation of temperature was caused by seasonal changes in the weather conditions (Table 1).

Table 1. The physical conditions of the air during all periods of the study

Tabela 1. Parametry fizyczne podczas prowadzenia badań

\begin{tabular}{|c|c|c|c|c|}
\hline \multicolumn{5}{|c|}{ Humidity - Wilgotność [\%] } \\
\hline & $\begin{array}{l}\text { period } \\
\text { pobór I }\end{array}$ & $\begin{array}{l}\text { period } \\
\text { pobór II }\end{array}$ & $\begin{array}{c}\text { period } \\
\text { pobór III }\end{array}$ & $\begin{array}{c}\text { period } \\
\text { pobór IV }\end{array}$ \\
\hline $\begin{array}{l}\text { Warehouse } \\
\text { Magazyn I }\end{array}$ & $48.9 \pm 1.5$ & $62.1 \pm 1.6$ & $60.0 \pm 2.1$ & $46.6 \pm 1.8$ \\
\hline $\begin{array}{l}\text { Warehouse } \\
\text { Magazyn II }\end{array}$ & $46.2 \pm 2.1$ & $61.8 \pm 2.0$ & $59.1 \pm 1.8$ & $44.3 \pm 2.4$ \\
\hline \multicolumn{5}{|c|}{ Temperature - Temperatura $\left[{ }^{\circ} \mathrm{C}\right]$} \\
\hline $\begin{array}{l}\text { Warehouse } \\
\text { Magazyn I }\end{array}$ & $18.7 \pm 0.5$ & $12.8 \pm 0.2$ & $9.8 \pm 0.3$ & $21.8 \pm 0.4$ \\
\hline $\begin{array}{l}\text { Warehouse } \\
\text { Magazyn II }\end{array}$ & $19.5 \pm 0.3$ & $13.4 \pm 0.3$ & $11.1 \pm 0.5$ & $22.4 \pm 0.4$ \\
\hline
\end{tabular}


The highest count of moulds during storage period was noted on stored grains. Average counts of fungi in the air, on storage surfaces and in the fallout microbial fraction were similar (Fig. 1).
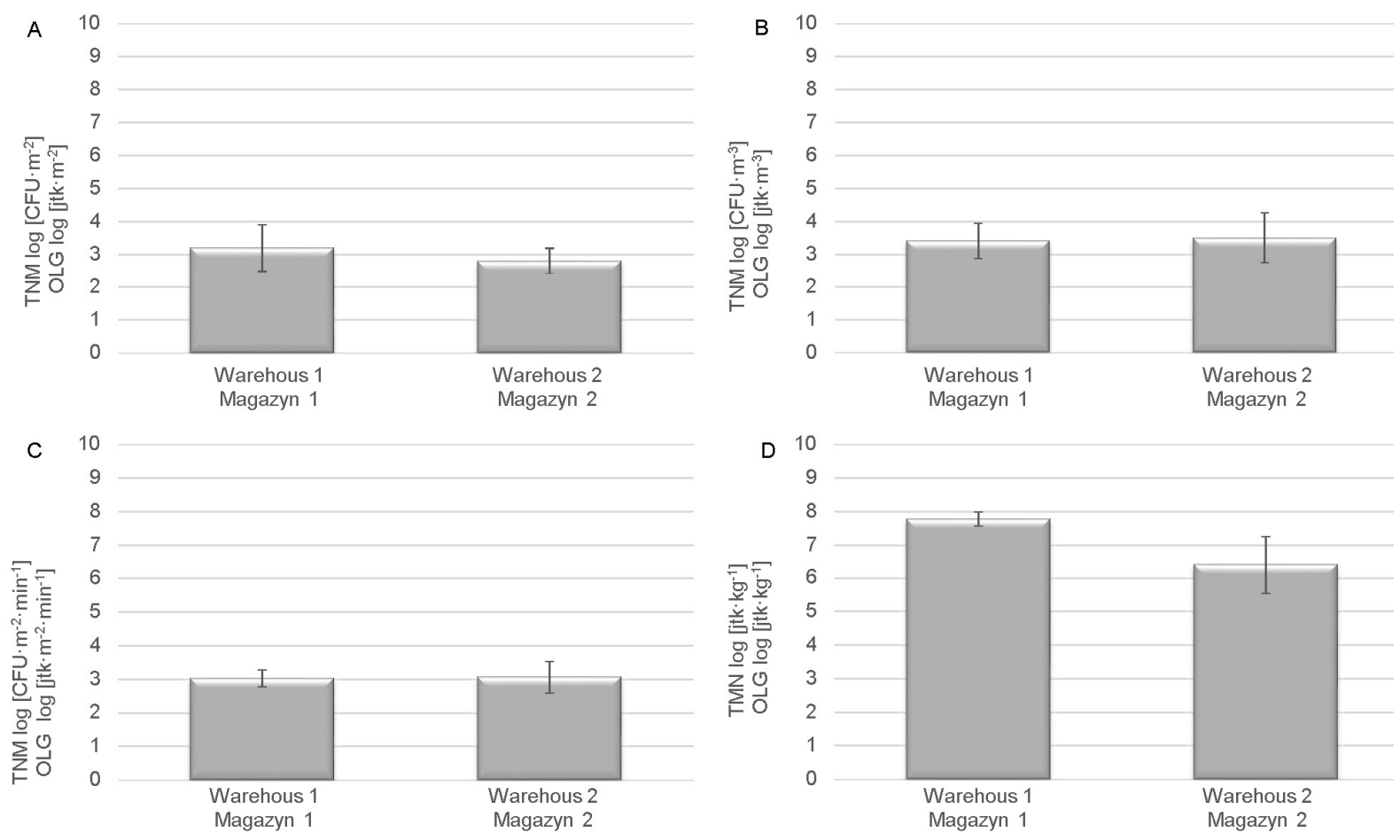

Fig. 1. Average total count of fungi in the cereal warehouses: on the storage surfaces (A), in the air (B), in the fallout microbial fraction (C) and in the storage grains (D)

Ryc. 1. Średnia ogólna liczba grzybów w magazynach zbożowych: na powierzchniach magazynowych (A), w powietrzu w magazynie (B), frakcji opadającej na powierzchnię magazynową (C) oraz w przechowywanym ziarnie zbóż (D)

The phytopathogenic fungi were not present in both warehouses before the process of filling with grain. Afterwards, Fusarium species were isolated from air and the sedimentation fraction of microorganism in the second warehouse during its filing, the storage period and after the evacuation period. Differently, the presence of Fusarium species changed in the first flat warehouse, where Fusarium was part of present moulds only during the second study period (after filling the warehouses process). The content of Fusarium species on the total number of moulds was higher in the second warehouse, but the proportion of this genera was shown the have a decreasing tendency. The highest number of Fusarium species was noted after the filling the warehouses with wheat grains. The dominant species was Fusarium graminearum, also isolated were $F$. aquaeductum $F$. oxysporum and $F$. poae. The Fusarium species did not occur on the warehouses walls (Table 2).

On the stored cereal grains, the presence of Fusarium isolates was only reported in the second warehouse. The highest share of Fusarium species $(55 \%)$ in the total number of moulds was found when the warehouses were filled. During storage, the quantitative ratio of Fusarium isolates to other moulds was characterized by a declining trend and finally was less than $22 \%$ (Fig. 2). 
Table 2. The share of Fusarium isolates in the total number of moulds on warehouses walls, in the air of the warehouses and in the fraction of microorganism that settled onto the warehousing surfaces for both warehouses respectively

Tabela 2. Udział grzybów z rodzaju Fusarium w ogólnej liczbie grzybów strzępkowych na powierzchniach magazynowych, w powietrzu magazynowym oraz frakcji opadającej na powierzchnię magazynową

\begin{tabular}{|c|c|c|c|c|}
\hline \multicolumn{5}{|c|}{ Walls of the warehouses - Ściany magazynów [\%] } \\
\hline & $\begin{array}{l}\text { period } \\
\text { pobór I }\end{array}$ & $\begin{array}{l}\text { period } \\
\text { pobór II }\end{array}$ & $\begin{array}{l}\text { period } \\
\text { pobór III }\end{array}$ & $\begin{array}{l}\text { period } \\
\text { pobór IV }\end{array}$ \\
\hline $\begin{array}{l}\text { Warehouse } \\
\text { Magazyn I }\end{array}$ & $0.00 \pm 0.00$ & $0.00 \pm 0.00$ & $0.00 \pm 0.00$ & $0.00 \pm 0.00$ \\
\hline $\begin{array}{l}\text { Warehouse } \\
\text { Magazyn II }\end{array}$ & $0.00 \pm 0.00$ & $0.00 \pm 0.00$ & $0.00 \pm 0.00$ & $0.00 \pm 0.00$ \\
\hline \multicolumn{5}{|c|}{ Air in the warehouses - Powietrze w magazynie [\%] } \\
\hline $\begin{array}{l}\text { Warehouse } \\
\text { Magazyn I }\end{array}$ & $0.00 \pm 0.00$ & $0.20 \pm 0.01$ & $0.00 \pm 0.00$ & $0.00 \pm 0.00$ \\
\hline $\begin{array}{l}\text { Warehouse } \\
\text { Magazyn II }\end{array}$ & $0.00 \pm 0.00$ & $1.24 \pm 0.06$ & $0.82 \pm 0.04$ & $0.48 \pm 0.02$ \\
\hline \multicolumn{5}{|c|}{$\begin{array}{c}\text { The fraction of microorganism that fall onto the warehousing surfaces } \\
\text { Frakcja opadająca na powierzchnię magazynu [\%] }\end{array}$} \\
\hline $\begin{array}{l}\text { Warehouse } \\
\text { Magazyn I }\end{array}$ & $0.00 \pm 0.00$ & $0.50 \pm 0.02$ & $0.00 \pm 0.00$ & $0.00 \pm 0.00$ \\
\hline $\begin{array}{l}\text { Warehouse } \\
\text { Magazyn II }\end{array}$ & $0.00 \pm 0.00$ & $5.00 \pm 0.21$ & $4.00 \pm 0.16$ & $3.50 \pm 0.17$ \\
\hline
\end{tabular}

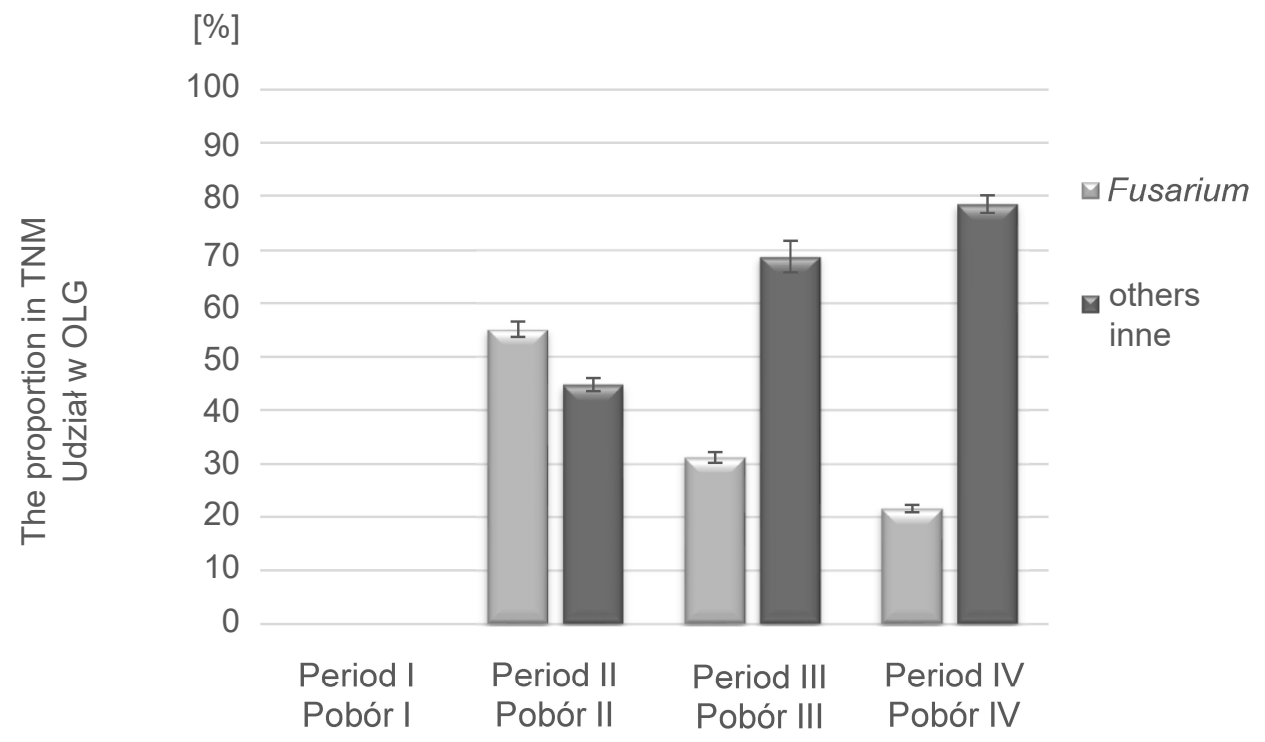

Fig. 2. The percentage proportion of Fusarium species in the total number of moulds on grain stored in the second warehouse (TNM)

Ryc. 2. Udział procentowy grzybów z rodzaju Fusarium w ogólnej liczbie grzybów strzępkowych (OLG) z ziarna przechowywanego w magazynie drugim (M2)

\section{DISCUSSION}

The physical conditions during the storage process were proper. The relative air humidity did not exceed the reference value (70\%). Czerwińska and Piotrowska (2010) caution that a higher air humidity favours growth of moulds, including the growth of Fusarium species. Czaban and co-authors (2015) in a field study have shown a dependence between the relative humidity of air, rainfall and the occurrence of Fusarium species on the grain surfaces. 
The highest infection degree was obtained for the most rainy season of 2008 than in other cultivation years when RH was lower than in 2008. Bernhoft et al. (2012) confirm that the climatic factors are correlated with the variation in the occurrence of Fusarium species and their mycotoxins in foodstuff. The high relative humidity of air before harvest time was found to increase the concentration of mycotoxins and the occurrence of Fusarium species.

The decline of the Fusarium species in stored grains to the total number of moulds depended on a decreasing of the air relative humidity. It may be associate with the humidity tolerance of Fusarium species. Common species of the genus grow and sporulate in high relative air humidity, so with a decline of the air humidity the xerophytes, as Aspergillus sp. and Penicillium sp., begin to predominate in the air (Fleurat-Lessard 2017).

The high percentage of Fusarium fungi in the stored grain, after filling of the second warehouse, indicates the contamination of the kernels with phytopathogenic fungi during crops cultivation. Czaban and co-workers (2015) highlight that the contents of deoxynivalenol and zearalenone in grain is correlated with the percentage of kernels colonised by Fusarium species, so assessment of Fusarium contamination in the stored grain may be an indicator of kernels quality. High number of Fusarium on grain may generate risk of mycotoxins contamination. Monitoring of participation of Fusarium in the total number of fungi can prevent by mycotoxins contamination.

A greater proportion of Fusarium fungi to the total number of moulds isolated from the fraction of microorganisms which settled onto the surfaces, to airborne moulds may be caused by differences in spore mass, size and density (Napoli et al. 2012). Macrospores produced by Fusarium species are larger than spores of xerophytic fungi as Aspergillus and Penicillium. However the relationship between the physical parameters and aerodynamic diameter of airborne spores is not well known (Reponen et al. 2001).

\section{CONCLUSIONS}

The highest average count od fungi was noted on the stored grain. The presence of Fusarium fungi during the cereal grain storage depends on the microbiological quality of the raw material. Reduction of the Fusarium sp. number during cereal storage is associated with the reduced humidity and increased storage temperature.

\section{REFERENCES}

Amiri A., Bompeix G. 2005. Diversity and population dynamics of Penicillium spp. on apples in preand postharvest environments: consequences for decay development. Plant Pathol. 54(1), 74-81.

Aok T., O'Donnell K., Geiser D.M. 2014. Systematics of key phytopathogenic Fusarium species: Current status and future challenges. J. Gen. Plant. Pathol. 80(3),189-201.

Bernhoft A., Torp M., Clasen P.E., Løes A.K., Kristoffersen A.B. 2012. Influence of agronomic and climatic factors on Fusarium infestation and mycotoxin contamination of cereals in Norway. Part A. Food Addit. Contam. Chem. Anal. Control Exp. Risk. Assess. 29(7), 1129-1140.

Champeil A., Doré T., Fourbet J.F. 2004. Fusarium head blight: epidemiological origin of the effects of cultural practices on head blight attacks and the production of mycotoxins by Fusarium in wheat grains. Plant Sci. 166(6), 1389-1415. 
Czaban J., Wróblewska B., Sułek A., Mikos M., Boguszewska E., Podolska G., Nieróbca A. 2015. Colonisation of winter wheat grain by Fusarium spp. and mycotoxin content as dependent on a wheat variety, crop rotation, a crop management system and weather conditions. Part A. Food Addit. Contam. Chem. Anal. Control Exp. Risk. Assess. 32(6), 874-910.

Czerwińska E., Piotrowski W. 2010. Ocena ryzyka zanieczyszczenia mikrobiologicznego w piekarni z uwzględnieniem procesu wytwarzania pieczywa żytniego [Evaluation of the microbiological contamination risk in bakery taking into account processing of light rye bread]. Nauka Przyr. Technol. 4, 1-15. [in Polish]

Demeke T., Clear R.M., Patrick S.K., Gaba D. 2005. Species-specific PCR-based assays for the detection of Fusarium species and a comparison with the whole seed agar plate method and trichothecene analysis. Int. J. Food Microbiol. 103(3), 271-284.

Fleurat-Lessard F. 2017. Integrated management of the risks of stored grain spoilage by seedborne fungi and contamination by storage mould mycotoxins. An update. J. Stored Prod. Res. 71, 22-40.

Jiménez-Islas H., Navarrete-Bolaños J.L., Botello-Álvarez E. 2004. Numerical study of the natural convection of heat and 2-D mass of grain stored in cylindrical silos. Agrociencia 38, 325-342.

Kręcidło Ł., Krzyśko-Łupicka T. 2015. Wrażliwość grzybów wyizolowanych z magazynów zakładu przemysłu spożywczego na wybrane olejki eteryczne [Sensitivity of molds isolated from warehouses of food production facility on selected essential oils]. Inż. Ekolog. 43, 100-108. [in Polish]

Kręcidło Ł., Krzyśko-Łupicka T. 2016. Geny warunkujące produkcję mykotoksyn u grzybów strzępkowych obecnych w magazynach zbożowych, w: Wybrane zagadnienia z biologii molekularnej oraz inżynierii materiałowej. Red. B. Zdunek, M. Szklarczyk. Lublin, TYGIEL, 106-122. [in Polish]

Krnjaja V., Levi J., Stankovi S., Petrovi T., Stojanovi L., Gogi M. 2012. Distribution of moulds and mycotoxins in maize grain silage in the trench silo. Biotechnol. Anim. Husb. 28, 845-854.

Landschoot S., Waegeman W., Audenaert K., Vandepitte J., Baetens J.M., De Baets B., Haesaert G. 2012. An empirical analysis of explanatory variables affecting Fusarium head blight infection and deoxynivalenol content in wheat. J. P. P. 94(1), 135-147.

Mohana D.C., Raveesha K.A. 2007. Anti-fungal evaluation of some plant extracts against some plant pathogenic field and storage fungi. J. Agr. Tech. 4(1), 119-137.

Napoli C., Tafuri S., Montenegro L., Cassano M., Notarnicola A., Lattarulo S. Montagna M.T., Moretti B. 2012. Air sampling methods to evaluate microbial contamination in operating theatres: results of a comparative study in an orthopaedics department. J. Hosp. Infect. 80(2), 128-132.

Pasquarella C., Pitzurra O., Savino A. 2000. The index of microbial air contamination. The J. Hosp. Infect. 46(4), 241-256.

Pasquarella C., Saccani E., Sansebastiano G.E., Ugolotti M., Pasquariello G., Albertini R. 2012. Proposal for a biological environmental monitoring approach to be used in libraries and archives. Ann. Agric. Environ. Med. 19(2), 209-212.

Pitt J.I., Hocking A.D. 2013. Fungi and food spoilage. 3rd ed. New York, Springer-Verlag.

Pitt J.I., Hocking A.D. 1985. A laboratory guide to common Penicillium species. Canberra, CSIRO.

Reponen T., Grinshpun S.A., Conwell K.L., Wiest J., Anderson M. 2001. Aerodynamic versus physical size of spores: Measurement and implication for respiratory deposition. Grana 40(3), 119-125.

Satish S., Raghavendra M.P., Mohana D.C., Raveesha K.A. 2008. Antifungal activity of a known medicinal plant Mimusops elengi L. against grain moulds. J. Agr. Tech. 4(1), 151-165.

Vanheule A., Audenaert K., Boevre M., Landschoot S., Bekaert B., Munaut F., Eeckhout M., Höfte M., De Saeger S., Haesaert G. 2014. The compositional mosaic of Fusarium species and their mycotoxins in unprocessed cereals, food and feed products in Belgium. Int. J. Food Microbiol. 181, 28-36.

Wegulo S.N., Baenziger P.S., Hernandez N.J., Bockus W.W., Hallen-Adams H. 2015. Management of Fusarium head blight of wheat and barley. Crop Prot. 73, 100-107. 
Abstract. Cereal grains on global scale provide more energy than other types of crops. They are a rich in carbohydrates and are the main source of this nutritional substances. Cereal and products made of it supply half of daily carbohydrate intake for average person. Over $80 \%$ of the worldwide grain production constitutes maize, wheat and rice. The main crops cultivated in Poland are wheat, rye, barley, oat and maize, because there are most conformed to the climate. The chain of agri-food production might be divided into three stages: the cultivation period, storage time and processing activities. At each of these stages there are different hazards in the production process including mycological contaminations. An severe issue is the contamination by the Fusarium species and production of mycotoxins by them. Fusarium species are capable of infecting the cultivated crops and may lead to decline the grain quality. The aim of this study was to determine the degree of contamination of grains and the storage area by Fusarium species during four storage periods. The study was conducted in four periods of research in two warehouses. The analysis included following assessments: the composition of the mycological bioaerosol from the warehouses, the number of microorganisms on the walls of the warehouses, the number of fungi in the fraction which settle on the surfaces of the warehouses and the microbiological quality of stored grain. Fusarium species were an insignificant part of the isolates from the surfaces of the warehouses. Microbiological quality of stored grain depended on the raw material and was different in each of the warehouses. The degree of grain contamination by Fusarium species decreased during the storage period. 